\title{
Distinguishing between Debris Flows and Floods from Field Evidence in Small Watersheds
}

\begin{abstract}
Dost-flood indirect measurement techniques to back-calculate flood magnitude are not valid for debris flows, which commonly occur in small steep watersheds during intense rainstorms. This is because debris flows can move much faster than floods in steep channel reaches and much slower than floods in low-gradient reaches. In addition, debris-flow deposition may drastically alter channel geometry in reaches where slope-area surveys are applied. Because high-discharge flows are seldom witnessed and automated samplers are commonly plugged or destroyed, determination of flow type often must be made on the basis of field evidence preserved at the site.
\end{abstract}

High-discharge flows (often indiscriminately referred to as "flash floods") in streams draining small $\left(<20 \mathrm{~km}^{2}\right)$, steep watersheds can involve mixtures of water and sediment in varying proportions. The relative concentration of suspended sediment plays an important role in the behavior and hazards of flows. Three basic flow processes are generally recognized in streams, although (1) they represent a continuum, and boundaries between flow types are not sharp, and (2) any one flow event may exhibit different flow types at different points along the flow path and at different times during the same event. The three types of flow include:

Water Flow - The amount of suspended sediment is insufficient to substantially affect how flowing water behaves. Newtonian fluid properties are preserved. Water may appear very muddy; but most of the suspended sediment is transported near the bed. Bedload may include material up to boulder-size.

Hyperconcentrated Flow - The amount of suspended sediment is sufficient to significantly change fluid properties and sedimenttransport mechanisms. Large volumes of sand are transported in dynamic suspension throughout the water column, although maintenance of high sediment loads depends on flow velocity and turbulence. Flows can be highly erosive.

Debris Flow - Sediment and water mixture becomes a slurry, similar to wet concrete, capable of holding gravel-sized particles in suspension when flowing slowly or stopped. In steep canyons flow can achieve high velocities, transport large boulders in suspension, and cause catastrophic damage from impact or burial. In low-gradient channels and on alluvial fans flow can be slow, impeded by drier, coarse sediment at the flow margins, but it can nevertheless rapidly infill channels, divert streams, and destroy automobiles, buildings, and infrastructure.
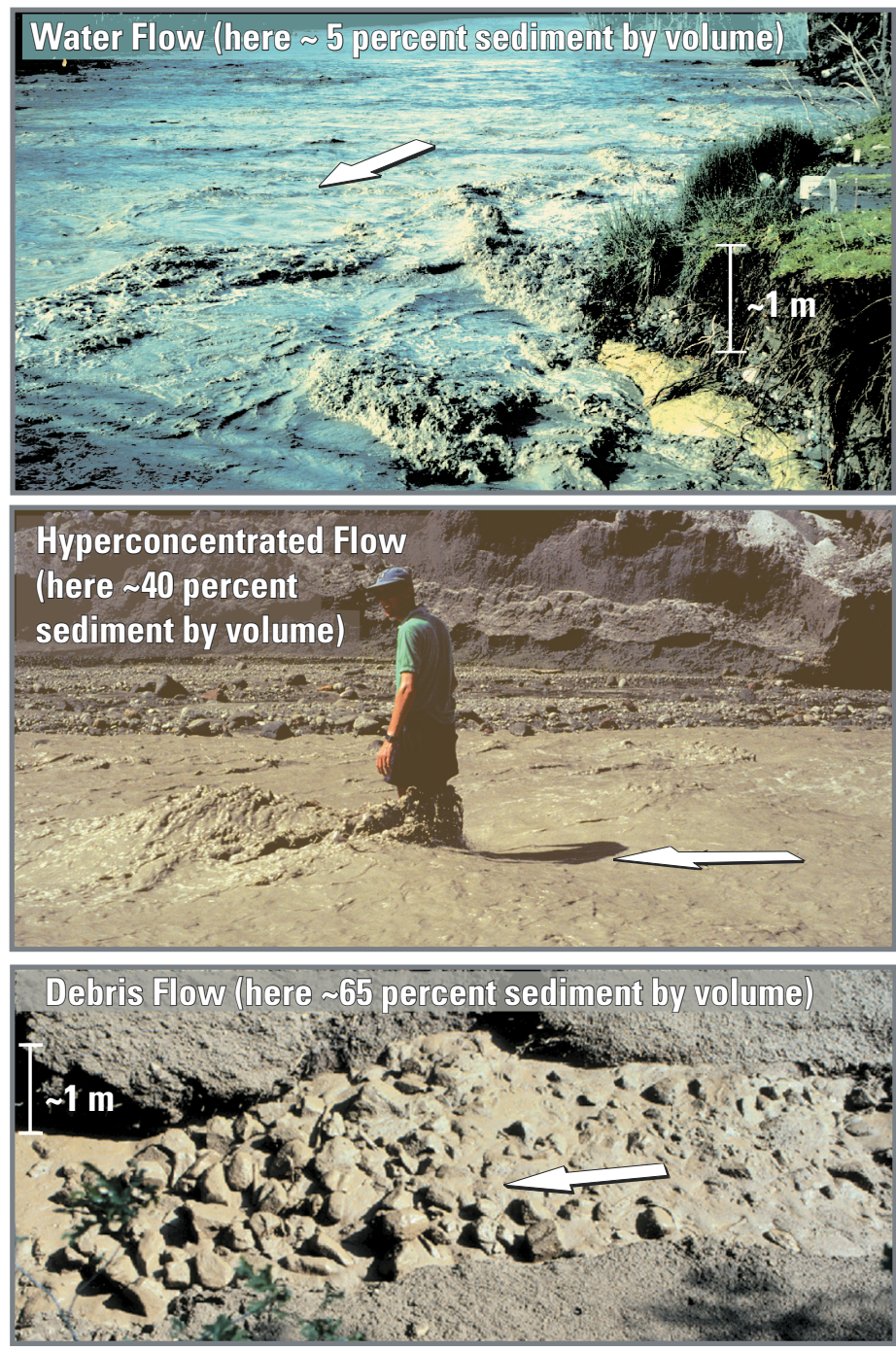

Arrows in above figures indicate flow direction

What's a "flood?"

For the purpose of this discussion, a flood is defined as a high discharge, overbank flow involving either water flow at "normal" suspended-sediment concentrations (generally less than 5-10 percent sediment by volume), or hyperconcentrated flow (having from 5-10 percent to anywhere between 20 - 60 percent sediment by volume, depending on the relative amount of silt and clay in the fluid mixture). In both cases, flow behavior is controlled by the water. Flow behavior of debris flows, in contrast, is significantly controlled by the entrained sediment. 


\section{DEBRIS FLOW OR FLOOD?}

\section{Debris Flow}

\section{Deposit Margins/Surfaces}

- No dunes or ripples on surface

- Lobate margins

-Accumulations of coarse clasts at margins (typically openwork); otherwise coarse clast distribution on surface is fairly random

- Positive relief (convex surface morphology where flow "freezing" occurs); surfaces commonly studded with boulders

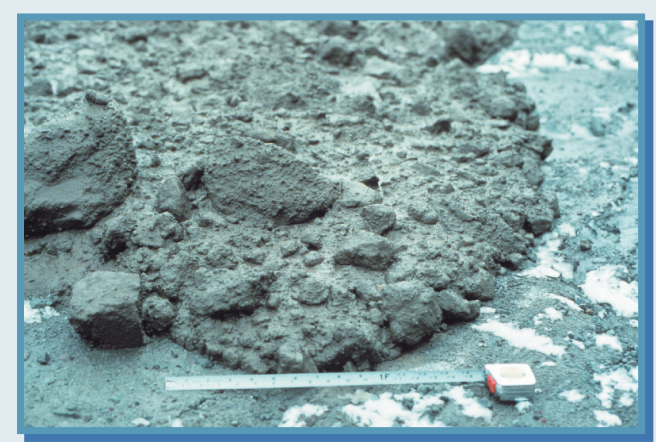

- Flow levees common but not always formed

- Consolidated sediments packed into "nooks and crannies" - e.g., between roots in root wads, in cavities in trees, buildings, stream banks, etc.

-Deposits frequently dammed locally by small log jams or boulder clusters

- Fragile clasts may be present on surface (e.g., soil clasts, glass bottles)

- Sandy mud coatings on boulders, logs, banks

- No gravel imbrication

\section{Channel Cross Section}

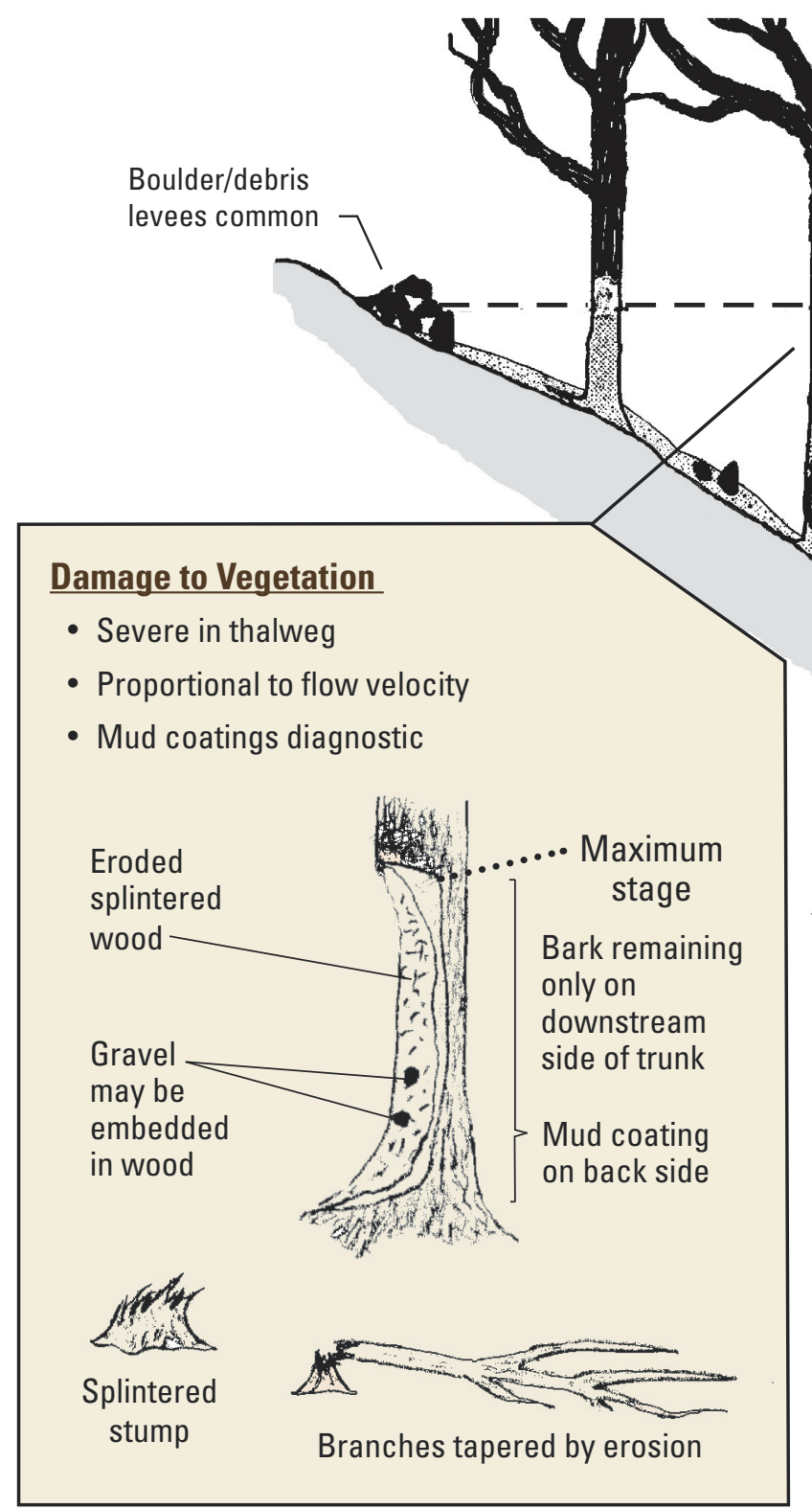

Runup on upstream side of obstacles proportional to flow velocity

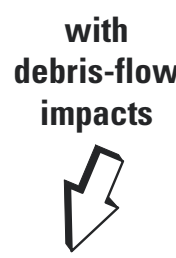

Maximum stage

Deposits commonly thicker toward center Muddy/sandy coatings of channel and banks

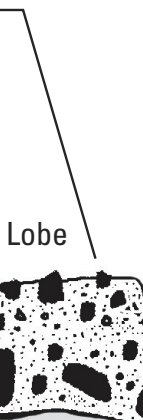

\section{Key Points to Remember in Field Evaluations}

- Consider all the evidence available - stratigraphic, sedimentologic, geomorphic, and effects on vegetation and structures; not all features may be present.

- A high-discharge event may involve different flow types; later part of flow may modify evidence left by earlier part of flow. For example, a debris flow peak may be followed (and typically is ) by recessional hyperconcentrated flow or water flow that may veneer the debris-flow deposit with fluvial sediments or erode and rework part of the debris-flow deposit.

- Examine channel over wide area (not just at gage site) 


\section{FIELD EVIDENCE}

Flood

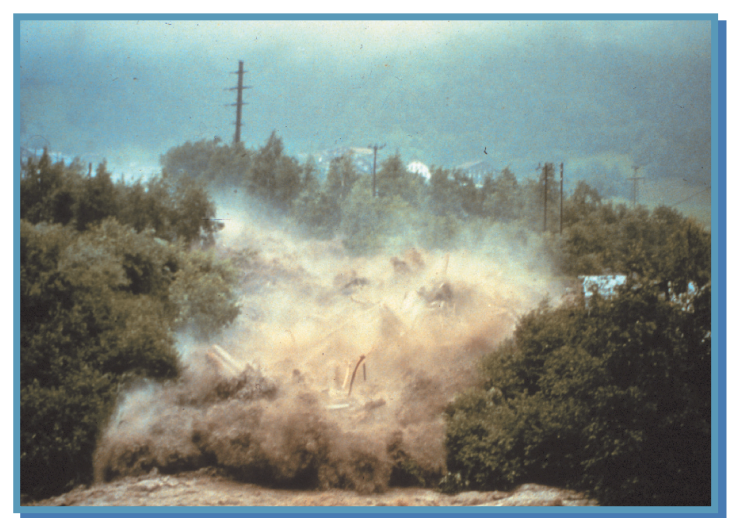

(C) Photo courtesy of Toni Venzin, 1987, Trun, Switzerland

High velocity debris flow in Swiss Alps

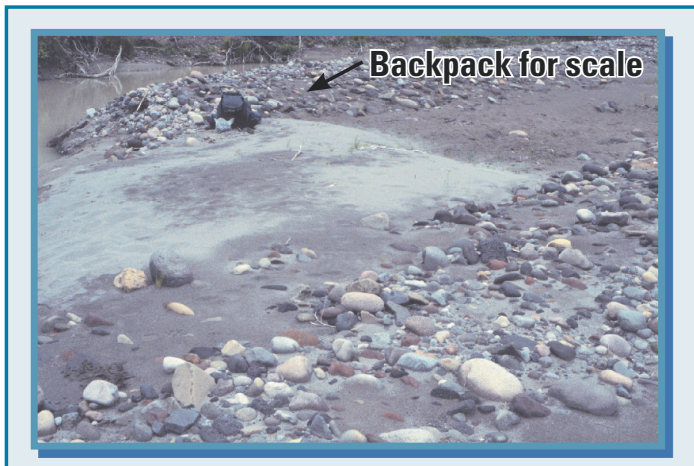

Deposit Margins/Surfaces

- Dunes, ripples common on water flow deposits (WFDs); no ripples/dunes on hyperconcentrated flow deposits (HCFDs)

- Longitudinal bars frequent on WFDs (typically armored with coarse clasts); coarse clasts concentrated in bars

- Surfaces cut by channels and scour depressions; HCFD surfaces usually studded more randomly with cobbles and boulders than WFDs

- Gravel levees do not form, though flotsam may accumulate at flow margins

- No mud coatings on boulders, logs, or banks

- Gravel clasts may be imbricated

\section{Looking Downstream}

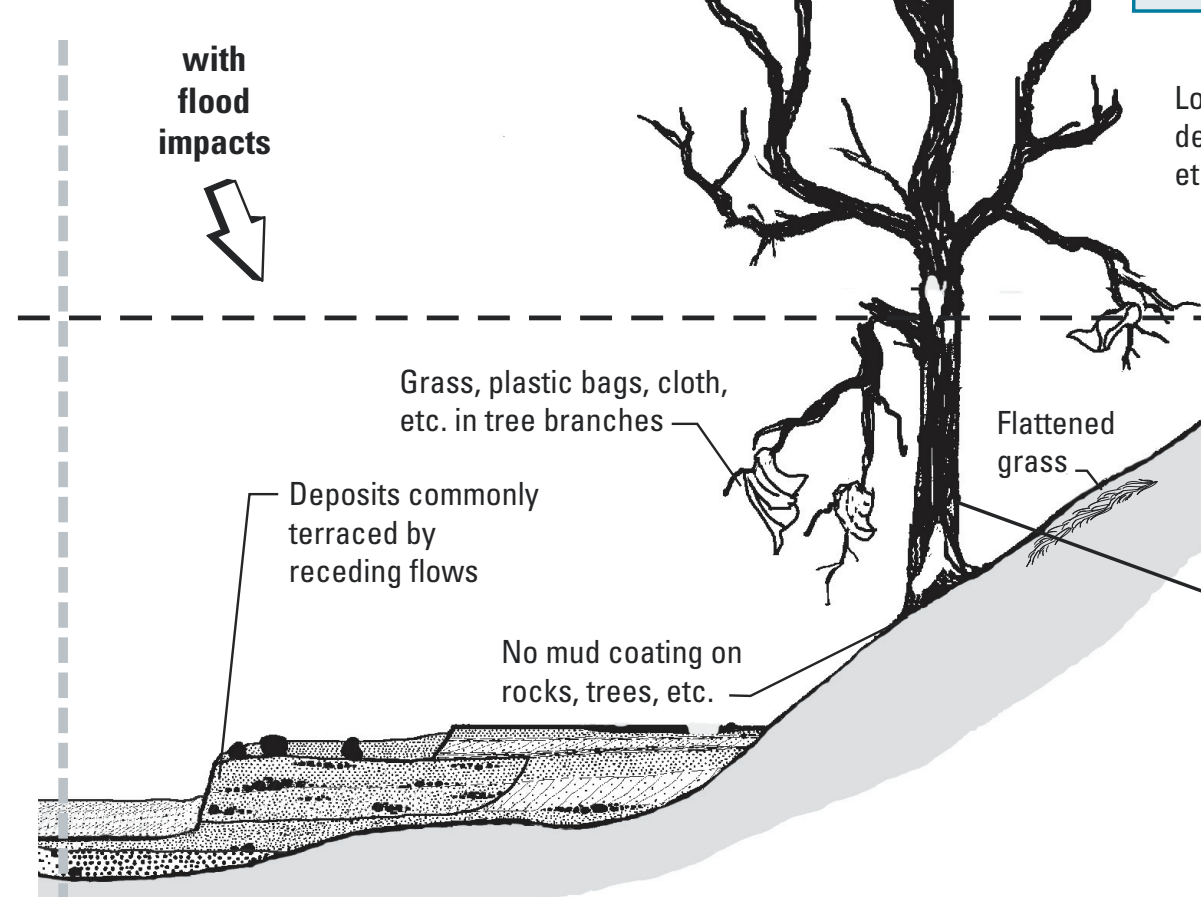

\section{Slope-Area Measurements for Debris Flow}

Although peak discharge is the standard indicator of flood magnitude and the desired datum for USGS flood data bases, seldom can it be determined reliably for debris flows by slope-area measurements. This is because debris-flow velocity cannot be predicted by the Manning equation, owing to complex factors that affect flow resistance in dense sediment slurries and preclude accurate determination of Manning's " $n$." For example, boulder fronts can add friction at the head of flow, while incorporation of sediment into a flow or deposition of sediment from a flow will alter the bulk rheology and grain-fluid interactions, and flow velocities can be profoundly affected. Furthermore, the usefulness of a peak discharge measurement for a debris flow (if obtained at a critical-depth site, for example) is limited because orders-of-magnitude changes in peak discharge can occur over very short distances (hundreds of meters) downstream. Estimates or measurements of total planimetric area inundated or total volume delivered beyond a canyon mouth are more useful data for some hazard assessments.

\section{Damage to Vegetation}

- Normally moderate to light; can be severe in steep canyons

- No mud coatings

- Erosion of tree bark usually light and irregular; concentrated near bed (from saltating bed material) and near (sometimes above) maximum stage (from floating debris)

- Finer branches commonly bent but not broken or stripped

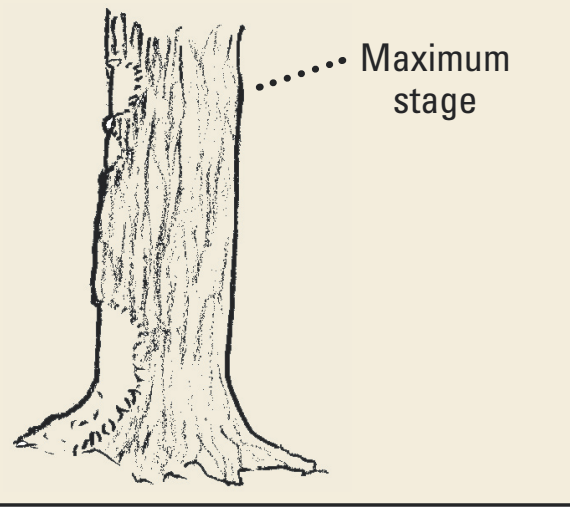




\section{Sediment Bedding and Textures}

\section{Flood Deposits}

- Most grains (all sizes) are rounded to subrounded (stream bed source)

- WFD sediments usually stratified - distinct laminae and beds, commonly with cross-bedding; HCFDs show faint horizontal to massive bedding with outsized individual gravel clasts and lenses sometimes appear as massive but poorly consolidated diamictons

- In WFDs, abrupt changes in mean grain size in vertical sections; sorting moderate to good within individual bedding units; coarser clasts may be imbricated

- In HCFDs, sorting usually poor to very poor; textural changes usually not abrupt

- Voids common between larger clasts (openwork texture) in water-flow deposits, not in HCFDs

- WFD consistency is loose and friable when dry (easy to dig), although HCFDs slightly more consolidated

- WFD surfaces commonly have longitudinal bars (usually armored with coarse clasts), dunes, and/or ripples; abrupt changes in mean grain size between bars and channel axes are typical

\section{Vertical Sections of Coarse Water-Flow Deposits}
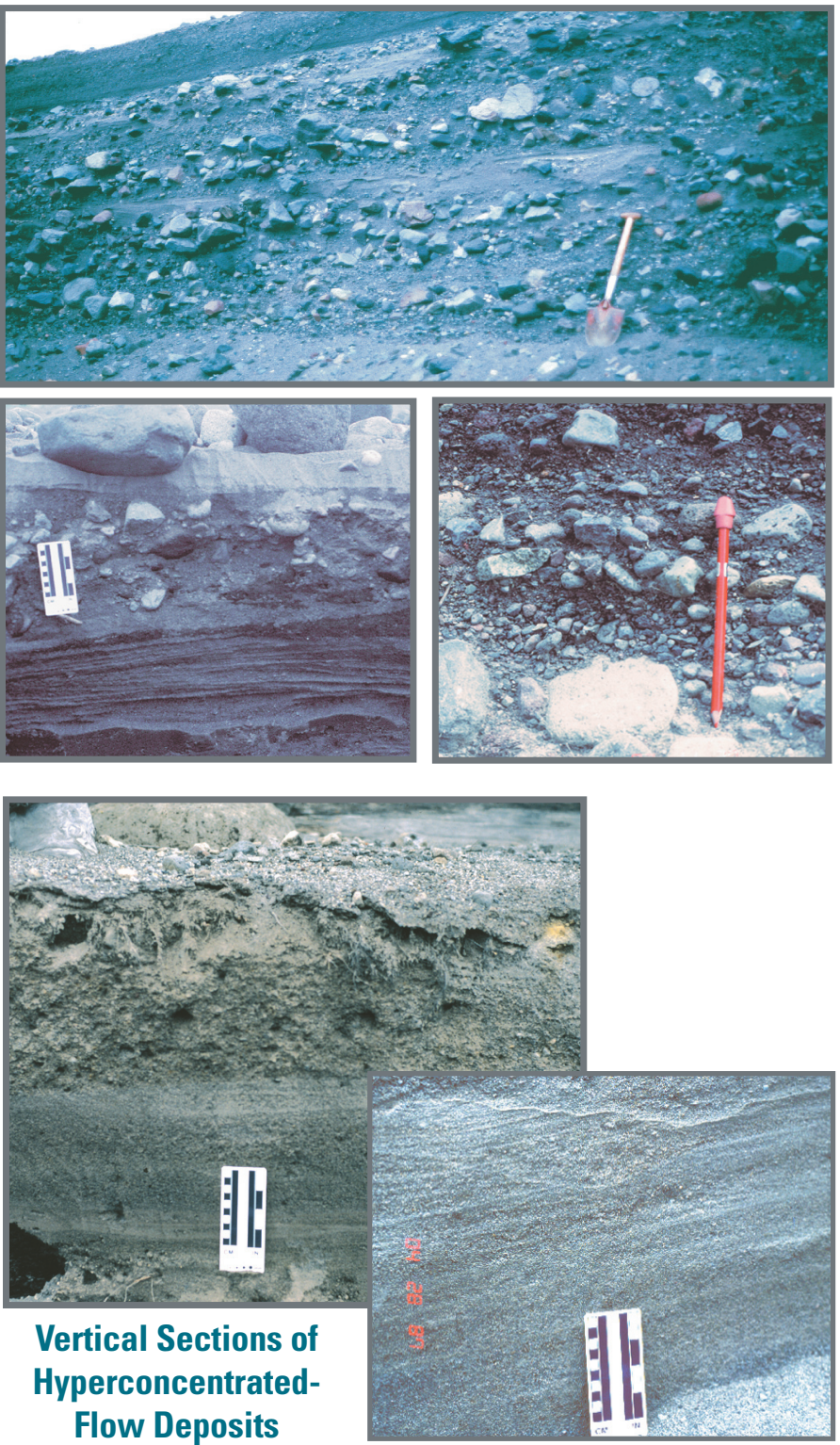

\section{Debris-Flow Deposits}

- Sand and fine gravel grains typically angular to subangular (hillslope source)

- Nonstratified, extremely poorly sorted (= massive diamictons)

- Normal and/or inverse grading common in vertical sections

- Matrix filling all voids except at margins or where washed out

- Coherent, semi-indurated consistency; difficult to dig-outcrops break off in small chunks when struck or kicked

- Multiple flow units commonly indistinguishable stratigraphically

- Coarse-clast distribution fairly random in centers of deposit surfaces but more concentrated at deposit margins; deposit surfaces commonly convex upward

- Clasts oriented randomly except at flow margins

\section{Vertical Sections of Debris-Flow Deposits}
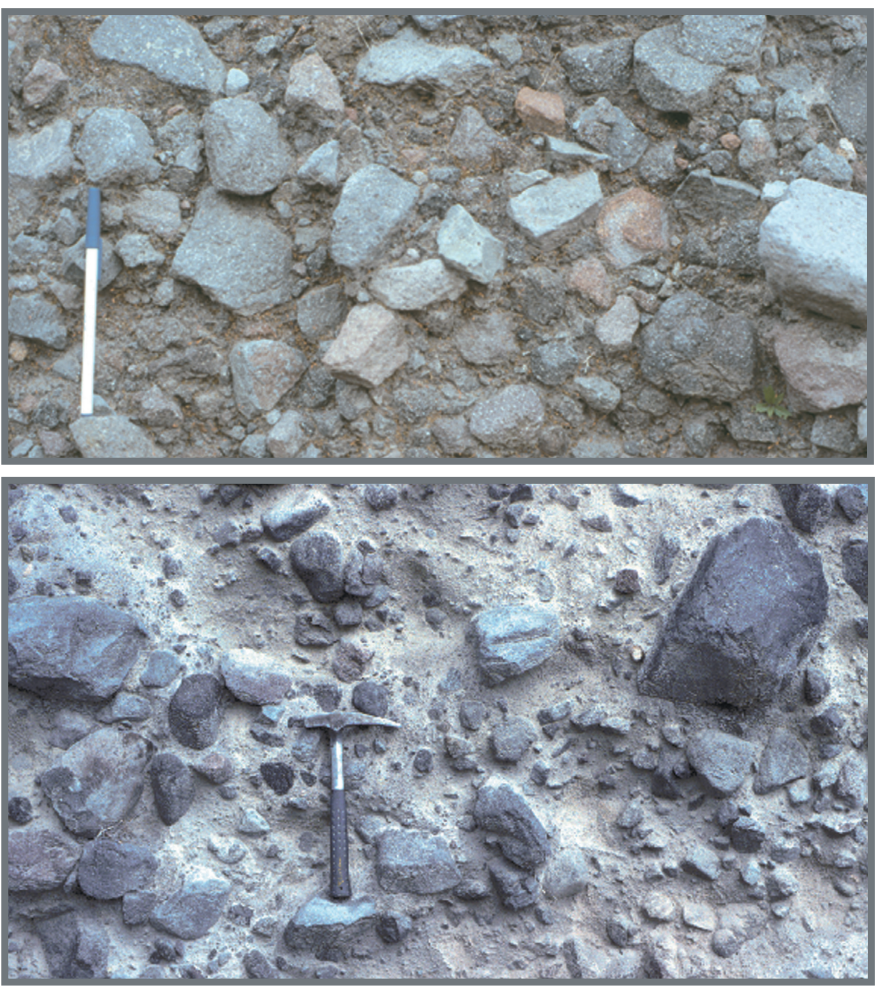

\section{Thomas C. Pierson}

Graphics and design by Christine Janda and Bobbie Myers Photographs by T.C. Pierson, except as labeled

\section{References for more information:}

Costa, J.E., 1988, Rheologic, geomorphic, and sedimentologic differentiation of water floods, hyperconcentrated flows, and debris flows, in Baker, V.R., Kochel, R.C., and Patten, P.C. (eds) Flood Geomorphology: Wiley-Intersciences, New York, p. 113-122

Jakob, M., and Hungr, 0., 2005, Debris Flow Hazards and Related Phenomena: Springer-Praxis, Heidelberg

\section{For more information, contact:}

U.S. Geological Survey, Cascades Volcano Observatory 1300 SE Cardinal Court, Suite 100, Vancouver, WA 98683 Tel: (360) 993-8900; Fax: (360) 993-8980

\section{http://vulcan.wr.usgs.gov/}

or

USGS Volcano Hazards Program http://volcanoes.usgs.gov/ 